Note

\section{(-)-Sclerosporin, an Antifungal Metabolite of Diplocarpon mali}

\author{
Ko SAwaI, Toshikatsu OKUno \\ and Eriko Yoshikawa \\ Faculty of Agriculture, Hirosaki University, \\ Hirosaki 036, Japan
}

Received March 11, 1985

During a search for metabolic products of Diplocarpon mali ${ }^{1}{ }^{1}(-)$-sclerosporin was isolated from culture liquid of the fungus. In this paper, we report the isolation of (-)sclerosporin and its antifungal property.

D. mali was stationarily grown in potato sucrose $(2 \%)$ broth at $20^{\circ} \mathrm{C}$ for 2 months. The culture filtrate $(\mathrm{pH} 6.3$, 30 liters) was extracted with chloroform three times. The extract $(1.1 \mathrm{~g})$ was subjected to silica gel column chromatography $(2 \times 40 \mathrm{~cm})$ with chloroform containing ethanol $(2 \%)$ and $6 \mathrm{ml}$ fractions were collected. Crystalline material obtained from the fractions $(18 \sim 23)$ was recrystallized from petroleum ether. The yield of pure crystals was about $35 \mathrm{mg}$. The physicochemical properties of this substance were as follows: $\mathrm{mp} 163^{\circ} \mathrm{C},[\alpha]_{\mathrm{D}}^{26}-17^{\circ}(c=3.7$, $\left.\mathrm{CHCl}_{3}\right)$. UV $\lambda_{\max }^{\mathrm{MeOH}} \mathrm{nm}(\varepsilon): 223(7,400)$. IR $v_{\max }^{\mathrm{KBr}} \mathrm{cm}^{-1}: 3440$ (br), 2960, 2925, 2895, 1690, 1650, 1435, 1390, 1370, 1270. MS $m / z: 234.1580\left(\mathrm{M}^{+}, \mathrm{C}_{15} \mathrm{H}_{22} \mathrm{O}_{2}\right), 191.1062\left(\mathrm{C}_{12} \mathrm{H}_{15} \mathrm{O}_{2}\right)$, $173.0969 \quad\left(\mathrm{C}_{12} \mathrm{H}_{13} \mathrm{O}\right), \quad 147.1770 \quad\left(\mathrm{C}_{11} \mathrm{H}_{15}\right), \quad 135.0433$ $\left(\mathrm{C}_{8} \mathrm{H}_{7} \mathrm{O}_{2}\right), 123.0440\left(\mathrm{C}_{7} \mathrm{H}_{7} \mathrm{O}_{2}\right), 105.0702\left(\mathrm{C}_{8} \mathrm{H}_{9}\right), 91.0458$ $\left(\mathrm{C}_{7} \mathrm{H}_{7}\right) .{ }^{1} \mathrm{H}-\mathrm{NMR} \delta_{\mathrm{Me}_{4} \mathrm{Si}}^{\mathrm{CDCl}_{3}}: 0.82$ and $0.94(6 \mathrm{H}$, two d, $J=$ $7.1 \mathrm{~Hz}) ; 1.69(3 \mathrm{H}, \mathrm{s}) ; 1.50 \sim 2.20(9 \mathrm{H}, \mathrm{m}) ; 2.57(1 \mathrm{H}, \mathrm{d}, J=$ $11.5 \mathrm{~Hz}) ; 5.48(1 \mathrm{H}, \mathrm{s}) ; 7.13(1 \mathrm{H}, \mathrm{t}, J=3.3 \mathrm{~Hz}) .{ }^{13} \mathrm{C}-\mathrm{NMR}$ $\delta_{\mathrm{Me}_{4} \mathrm{Si}}^{\mathrm{CDCl}_{3}}: 15.1(\mathrm{q}), 21.3(\mathrm{q}), 23.8(\mathrm{q}), 25.6(\mathrm{t}), 26.4(\mathrm{t}), 29.7(\mathrm{t})$, 30.6 (d), 33.9 (d), 35.9 (d), 40.1 (d), 123.0 (d), 133.2 (s), 135.0 (s), 142.6 (d), 172.7 (s). The ${ }^{1} \mathrm{H}-\mathrm{NMR}$ and MS spectra were almost identical with those of sclerosporin reported by Katayama et al. ${ }^{2,3)}$ Therefore, this substance was found to be (-)-sclerosporin.
Since sclerosporin was reported to be a sporogenic substance toward Sclerotina fructicola, ${ }^{2 \sim 4)}$ it was examined as to whether (-)-sclerosporin shows a similar sporogenic activity under the following conditions. Different amounts $(1,10$ and $100 \mu \mathrm{g})$ of $(-)$-sclerosporin dissolved in $100 \mu$ l of acetone were added to $20 \mathrm{ml}$ of potato sucrose agar medium in $9 \mathrm{~cm}$ Petri dishes. After sterilization, a loop of $S$. fructicola was placed on the media followed by incubation at $20^{\circ} \mathrm{C}$ in the darkness or under continuous light, 1,700 lux from two fluorescent lamps (Toshiba FL 20 S.D/NL). As a control, a loop of the fungus was also placed on medium which was free from $(-)$-sclerosporin in the darkness or under illumination. After 4 days incubation, the mycelial growth area was measured, and at the same time spores were collected in $10 \mathrm{ml}$ water and counted in a Thoma haemocytometer. The results are shown in Table I. In the control, sporulation of $S$. fructicola was apparently inhibited by light. This result was similar to that of Harada, ${ }^{5}$ who reported that sporulation of $S$. fructicola was somewhat enhanced by light at $15^{\circ} \mathrm{C}$ and below but inversely affected at $20^{\circ} \mathrm{C}$ and above, and that, among Monilinia species, S. fructicola was the only one whose sporulation was accelerated by light at a low temperature and inhibited by it at a high temperature. Therefore, the sporulating processes of this fungus seem to be quite complex. In both dark and light cultures, the mycelial growth decreased as the amount of the sample increased, while the spore number was inversely affected, and the total spore numbers $(\mathrm{A} \times \mathrm{B}$ and $\mathrm{C} \times \mathrm{D})$ remained approximately constant with or without the sample, that is, $2.9 \times 10^{7} \sim 3.3 \times 10^{7}$ in the darkness and $2.6 \times 10^{6} \sim 2.9 \times 10^{6}$ in the light. Therefore, the spore formation seems to be inversely proportional to the growth inhibition. From the results, the spore increase observed in the presence of the sample may be considered to be due to accelerated mycelial maturation caused by the growth inhibition, and not due to the sporogenic activity of the sample itself. So, as to this problem, we examined the effect of $(-)$-sclerosporin on the spore formation of mature mycelia of $S$. fructicola. The fungus was grown at $20^{\circ} \mathrm{C}$ in the darkness in a $500 \mathrm{ml}$ Erlenmeyer flask containing $100 \mathrm{ml}$ of potato sucrose broth. After a week, when the surface of the liquid was covered

TABle I. EFFect of (-)-Sclerosporin on Sporulation and Growth oF S. fructicola.

\begin{tabular}{|c|c|c|c|c|c|c|}
\hline \multirow[b]{2}{*}{$\begin{array}{l}\text { Dose }(\mu \mathrm{g}) / \text { agar } \\
\text { medium }(1 \mathrm{ml})\end{array}$} & \multicolumn{3}{|c|}{ Dark } & \multicolumn{3}{|c|}{ Light } \\
\hline & $\begin{array}{l}\text { Growth area } \\
\left(\mathrm{cm}^{2}\right)=\mathrm{A}\end{array}$ & $\begin{array}{c}\text { Spore } \\
\text { number/growth } \\
\text { area }\left(1 \mathrm{~cm}^{2}\right)=\mathrm{B}\end{array}$ & $\begin{array}{l}\text { Total spore } \\
\text { number } \\
(\mathrm{A} \times \mathrm{B})\end{array}$ & $\begin{array}{l}\text { Growth area } \\
\left(\mathrm{cm}^{2}\right)=\mathrm{C}\end{array}$ & $\begin{array}{c}\text { Spore } \\
\text { number/growth } \\
\text { area }\left(1 \mathrm{~cm}^{2}\right)=\mathrm{D}\end{array}$ & $\begin{array}{l}\text { Total spore } \\
\text { number } \\
(\mathrm{C} \times \mathrm{D})\end{array}$ \\
\hline 0 & 28.5 & $1,046 \times 10^{3}$ & $3.0 \times 10^{7}$ & 16.3 & $166 \times 10^{3}$ & $2.7 \times 10^{6}$ \\
\hline 0.05 & 16.7 & $1,965 \times 10^{3}$ & $3.3 \times 10^{7}$ & 12.0 & $229 \times 10^{3}$ & $2.7 \times 10^{6}$ \\
\hline 0.5 & 9.0 & $3,320 \times 10^{3}$ & $3.0 \times 10^{7}$ & 5.0 & $586 \times 10^{3}$ & $2.9 \times 10^{6}$ \\
\hline 5 & 4.3 & $6,850 \times 10^{3}$ & $2.9 \times 10^{7}$ & 2.4 & $1,102 \times 10^{3}$ & $2.6 \times 10^{\epsilon}$ \\
\hline
\end{tabular}




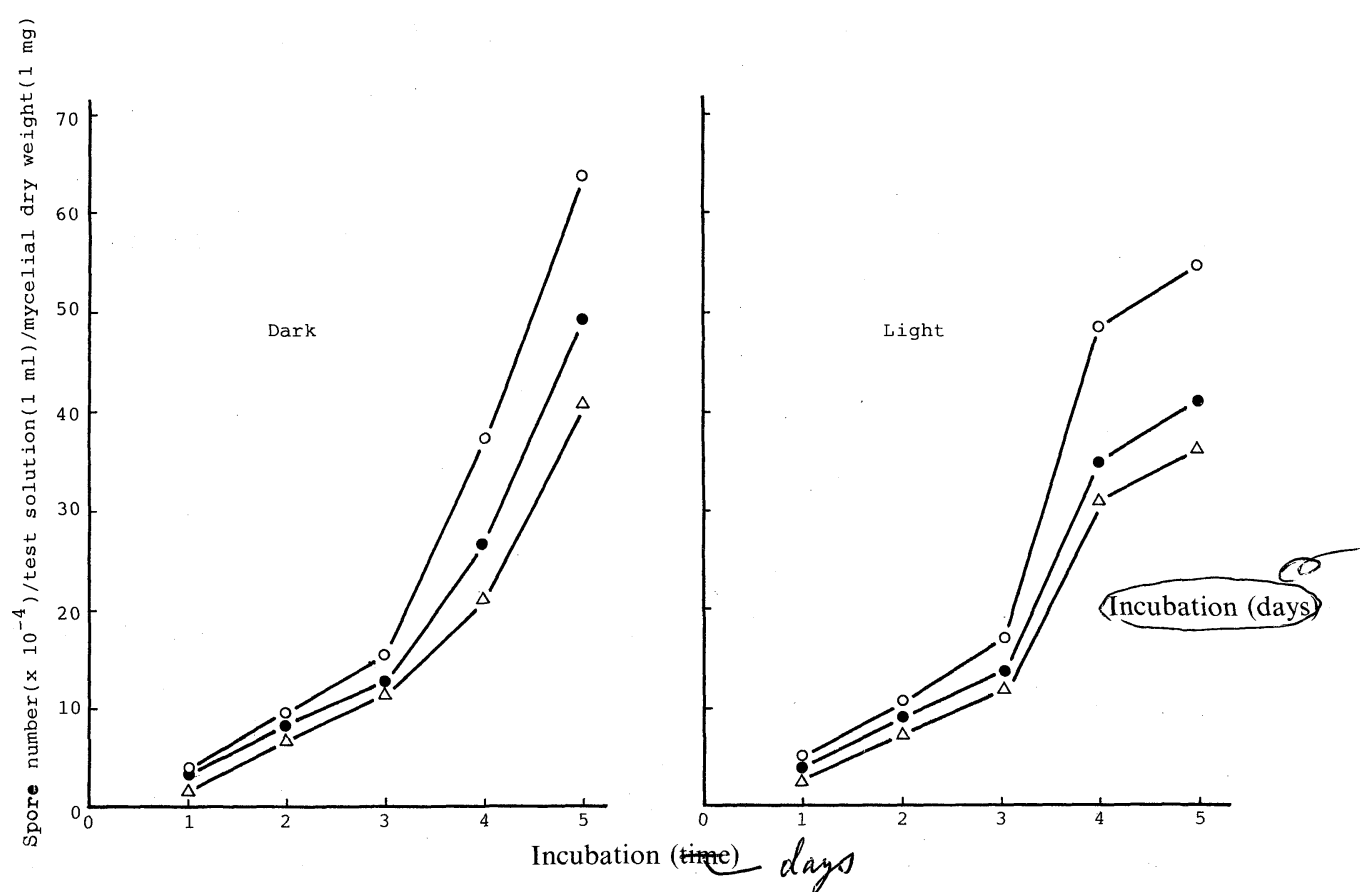

FIG. 1. Inhibitory Effect of (-)-Sclerosporin on Spore Formation of Mature Mycelia of $S$. fructicola on Dark and Light Incubation.

(-)-Sclerosporin concentrations $(\mu \mathrm{g} / \mathrm{ml}):-\bigcirc-, 0 ;-\bigcirc-, 0.5 ;-\triangle-, 5$. Each point is the mean for 4 determinations.

TABle II. ANTIFUngal ACtivity OF $(-)$-SClERosporin toward Several Plant Pathogens

\begin{tabular}{lc}
\hline & MIC \\
\cline { 2 - 2 } Test organism & $\begin{array}{c}\mu \mathrm{g} \text { of }(-) \text {-sclerosporin/ } \\
\text { medium }(1 \mathrm{ml})\end{array}$ \\
\hline Rosellinia necatrix & 5 \\
Valsa ceratosperma & 25 \\
Pyricularia oryzae & 100 \\
Stereum purpureum & $>100$ \\
Fusarium solani & $>100$ \\
Diplocarpon mali & $>100$ \\
\hline
\end{tabular}

with mycelia, the mycelia were harvested, washed several times with distilled water to eliminate spores and then cut into disks with a $1 \mathrm{~cm}$ cork borer. After excess water had been blotted off with filter paper, each wet disk was incubated at $20^{\circ} \mathrm{C}$ in $2 \mathrm{ml}$ of an aqueous solution containing the sample $(0,1$, and $10 \mu \mathrm{g})$ dissolved in acetone $(40 \mu \mathrm{l})$ in the darkness and under illumination (1,700 lux). The number of spores in each solution was counted at daily intervals. After that, the dry weight of each disk was determined. As shown in Fig. 1, the spore number per the dry weight $(1 \mathrm{mg})$ of mature mycelia was obviously decreased with the sample in both darkness and under illumination, the inhibitory effect being more pronounced with light than with darkness. From the results, it was found that $(-)$-sclerosporin was not a sporogenic substance toward $S$. fructicola.

The antifungal activity of $(-)$-sclerosporin toward some plant pathogens other than S. fructicola was examined by the agar dilution method, and it was found to inhibit not only the growth of S. fructicola but also that of other pathogens. The minimum inhibitory concentration (MIC) of the sample for these pathogens are given in Table II. $R$. necatrix was the most sensitive to the sample.

The absolute configuration of (-)-sclerosporin was recently determined to be $\mathbf{1}$ by Kitahara et al. ${ }^{6}$<smiles>CC1=C[C@H]2C(C(=O)O)=CC[C@H](C(C)C)[C@H]2CC1</smiles>

Acknowledgments. The authors wish to express their sincere thanks to Dr. K. Sawamura and Dr. Y. Harada (Hirosaki University) for the kind gifts of D. mali. 


\section{REFERENCES}

1) Y. Harada, K. Sawamura and K. Konno, Ann. Phytopath. Soc. Jpn., 40, 412 (1974).

2) M. Katayama and S. Marumo, Agric. Biol. Chem., 42, 505 (1978).

3) M. Katayama and S. Marumo, Tetrahedron Lett., 1773 (1979).
4) M. Katayama and S. Marumo, Tetrahedron Lett., 24, 1703 (1983).

5) Y. Harada, Bull. Fac. Agric. Hirosaki Univ., 27, 30 (1977).

6) T. Kitahara, T. Matsuoka, M. Katayama, S. Marumo and K. Mori, Tetrahedron Lett., 25, 4685 (1984). 